\title{
THE LEVEL OF TEACHING TECHNICAL EDUCATION AT RECENT SCHOOL
}

\section{Danka LUKÁČOVÁ}

Resumé: The contribution points at the problems and level of teaching technical education in a contemporaly schol. The author introduces the results of a research that has been realized in districts of Nitra. The research was focused on the realization of contens of teaching of technical education at the second level of basic schools and eight-year grammar schools

Kl'účové slová anglicky: the level of teaching technical education, basic schools, eight-year grammar schools

\section{ÚROVEŇ VYUČOVANIA TECHNICKEJ VÝCHOVY V SÚČASNEJ ŠKOLE}

Resumé: V príspevku je poukázané na problematiku a úroveň vyučovania technickej výchovy $v$ súčasnej škole. Autor uvádza výsledky prieskumu, ktorý bol realizovaný v okrese Nitra. Prieskum bol zameraný na realizáciu obsahu vyučovania technickej výchovy na 2. stupni základných škôl a v osemročných gymnáziách.

Kl'účové slová: úroveň vyučovania, základné školy, osemročné gymnáziá

Úvod

Všeobecné technické vzdelávanie predstavuje na Slovensku systém celoživotného vzdelávania, ktorý sa realizuje:

- v predškolskej výchove v materských školách,

- na 1. stupni základnej školy v 1. a 2. ročníku $v$ integrovanej podobe v predmete výtvarná výchova a v 3. a 4. ročníku ako samostatný predmet pracovné vyučovanie,

- na 2. stupni základnej školy v predmete technická výchova,

- na stredných odborných školách a učilištiach prehlbovaním poznatkov prostredníctvom odborného vzdelávania v oblasti techniky,

- na vysokých školách a univerzitách technického zamerania,

- podl'a ponúk vysokých škôl, univerzít a ostatných vzdelávacích inštitúcií v rámci celoživotného vzdelávania prostredníctvom univerzít tretieho veku a rôznych kurzov.

V našom výskume sme sa zamerali na zist'ovanie vedomostnej úrovne 15 - ročných žiakov z oblasti techniky, aby sme zistili úroveň technickej gramotnosti žiakov končiacich základnú školu a porovnali ich s výsledkami žiakov študujúcich na osemročných gymnáziách. Títo žiaci nemajú v učebnom pláne povinný predmet priamo súvisiaci s technickým vzdelávaním, ale obsah niektorých predmetov (matematika, fyzika, chémia, biológia, informatika) postihuje aj problematiku učiva z oblasti techniky.

\section{Ciel'}

Ciel’om nášho výskumu bolo zistenie úrovne technického vzdelania $\mathrm{v}$ populácii 15 - ročných žiakov. Pre splnenie tohto ciel'a sme si vytýčili nasledovné úlohy:

- Zistit' úroveň vedomostí 15 ročných žiakov, pričom títo žiaci budú rozdelení do dvoch skupín:

1. skupina: žiaci 9. ročníka ZŠ,

2. skupina: žiaci kvinty osemročného gymnázia.

- Zistit', či výkon stanovený percentom úspešnosti žiakov v didaktickom teste dosiahnu žiaci v oboch skupinách.

- Zistit', či žiaci základných škôl, ktorí majú technické vzdelávanie v predmete technická výchova dosahujú v didaktickom teste lepšie výsledky ako žiaci osemročných gymnázií, ktorí tento predmet nemajú.

Pre splnenie týchto ciel'ov navrhujeme overenie hlavnej hypotézy:

H: Technické vzdelávanie realizované v povinnom predmete je efektívnejšie ako technické vzdelávanie realizované medzipredmetovými väzbami. 
Z tejto hlavnej hypotézy vychádzajú nasledovné pracovné hypotézy:

H(1): Rozdiel medzi dosiahnutým výsledkom 15 - ročných žiakov základných škôl a stanoveným výkonom (80 \%) nie je štatisticky významný.

$\mathrm{H}(2)$ : Rozdiel medzi dosiahnutým výsledkom 15 - ročných žiakov základných škôl a stanoveným výkonom (80 \%) nie je štatisticky významný.

H(3): 15 - roční žiaci základných škôl dosiahnu v didaktickom teste vyšší výkon voblasti kognitívneho učenia ako žiaci osemročných gymnázií.

Výskumnú vzorku tvorilo 76 žiakov 9. ročníka ZŠ a 17 žiakov osemročného gymnázia.

Ako prostriedok na hodnotenie vedomostí z oblasti technického vzdelávania sme si zvolili didaktický test. Aby počet otázok korešpondoval s časovou dotáciou, ktorá bola danému tematickému celku určená, rozhodli sme sa každý tematický celok overovat' rovnakým počtom otázok ako bol stanovený počet hodín. Stanovené výkony (percentuálna úspešnost' testu) boli konzultované formou rozhovorov počas seminára pre učitel'ov technickej výchovy, ktorý bol usporiadaný katedrou technickej výchovy PF UKF v Nitre v marci r. 2008.

Hlavnou výskumnou metódou bol prirodzený pedagogický experiment. Závisle premennou bol výkon žiakov, ktorý dosiahli jednotlivé experimentálne skupiny a nezávisle premennými boli rôzne skupiny žiakov základných škôl a gymnázií, ktoré boli zaradené do experimentu.

Didaktický test obsahoval učivo stanovené vzdelávacím štandardom pre technickú výchovu v 8. ročníku základnej školy. Toto učivo sme volili z dvoch dôvodov. Po prvé, v deviatom ročníku ZŠ je možnost' úplného výberu učiva učitel'om predmetu a teda nebola by možnost' zostavit' taký test, ktorý by bol vhodný pre všetkých respondentov. Po druhé, učivo ôsmeho ročníka nebolo pre deviatakov novým učivom a tak nemali výhodu oproti žiakom osemročných gymnázií, ktorí vedomosti čerpali $\mathrm{z}$ učiva prírodovedných predmetov.

Test bol zameraný na úroveň osvojenia učiva definovaného obsahovým a výkonovým štandardom, t. j. ide o kognitívny, výstupný, CR-rozlišujúci, neštandardizovaný didaktický test. Obsahom testu bolo základné učivo technickej výchovy v 8. ročníku ZŠ vyučované v rozsahu 13 hodín. Počet úloh v teste bol 10 .
Pri oprave didaktického testu sme použili binárne skórovanie: jeden bod za správnu odpoved', nula bodov za nesprávnu, neúplnú alebo vynechanú odpoved’. Za každú správne zodpovedanú úlohu bol žiakovi pridelený jeden bod. Spolu teda mohol dosiahnut' každý žiak skóre 10 bodov.

Pätnástroční žiaci základných škôl dosiahli $\mathrm{v}$ didaktickom teste nasledovné hodnoty:

Aritmetický priemer: $\mathrm{x}_{1}=4,78(47,8 \%)$

Smerodajná odchýlka: $\mathrm{s}_{1}=1,8$

Pätnástroční žiaci osemročných gymnázií dosiahli v didaktickom teste nasledovné hodnoty: Aritmetický priemer: $\mathrm{x}_{2}=3,53$ (35,3 $\%)$

Smerodajná odchýlka: $\mathrm{s}_{2}=1,5$

Pre overenie hypotéz $H(1), H(2)$ sme vybrali neparametrický test , $\chi^{2}-$ test dobrej zhody“ podl'a K. Pearsona. Pre overenie hypotézy H(1) sme vypočítali testovacie kritérium: $\chi^{2}=$ 129,13. Našli sme tabul'kovú kritickú hodnotu (Šimková,1985, s. 242): $\chi_{75}^{2}(0,05)=90,53$. Platí $\chi^{2}>90,53$, teda hypotéza $\mathrm{H}(1)$ sa nepotvrdila na hladine významnosti $\alpha=0,05$. Žiaci, ktorí boli vyučovaní v oblasti techniky na základnej škole, nedosiahli v didaktickom teste určený výkon $80 \%$.

$\mathrm{Na}$ overenie hypotézy $\mathrm{H}(2)$ sme vypočítali testovacie kritérium: $\chi^{2}=47$. Nájdeme tabul'kovú kritickú hodnotu (Šimková,1985, s. 242): $\chi_{16}^{2}(0,05)=26,3$. Platí $\chi^{2}>79,08$, teda hypotéza $\mathrm{H}(2)$ sa nepotvrdila na hladine významnosti $\alpha=0,05$. Žiaci, ktorí boli vyučovaní $\mathrm{v}$ oblasti techniky na osemročných gymnáziách nedosiahli v didaktickom teste určený výkon $80 \%$.

Pre overenie hypotézy $H(3)$ sme použili analýzu rozptylu. Jedným z predpokladov použitel'nosti analýzy rozptylu sú rovnaké hodnoty parametra $\sigma^{2}$ normálneho rozdelenia sledovanej náhodnej veličiny $X$ vo všetkých skupinách, ktoré majú byt' porovnané. Tento predpoklad sme overovali Bartlettovým testom. Potom sme uskutočnili analýzu rozptylu, ktorá testovala hypotézu o rovnosti stredných hodnôt skúmanej veličiny - skóre žiakov dosiahnuté $\mathrm{v}$ didaktickom teste. Na testovanie kontrastov sme použili Duncanov test.

Bartlettov test mal hodnoty: $\mathrm{C}=1,02$, hodnotu testovacieho kritéria $\mathrm{B}=0,7$. Z tabuliek kritických hodnôt chí - kvadrát rozdelenia sme zistili hodnotu (Komenda, Klementa, 1981, s. 302): $\chi_{0,95}^{2}(1)=3,84$. Platí 
B $<3,84$ a teda hypotéza homogenity rozptylov sa pripúšt'a ako platná. Bolo teda možné uskutočnit’ analýzu rozptylu (tab. 1).

\begin{tabular}{|c|c|c|l|c|}
\hline Variabilita & $\begin{array}{c}\text { Súčet } \\
\text { štvorcov }\end{array}$ & $\begin{array}{c}\text { Počet } \\
\text { st. vol'. }\end{array}$ & $\begin{array}{c}\text { Roz- } \\
\text { ptyl }\end{array}$ & $\begin{array}{c}\text { Hodnota } \\
\text { F }\end{array}$ \\
\hline Celková & 301,03 & 92 & & \\
\hline $\begin{array}{c}\text { Medzi } \\
\text { skupinami }\end{array}$ & 21,6 & 1 & 21,6 & 7,03 \\
\hline $\begin{array}{c}\text { Vnútri } \\
\text { skupín }\end{array}$ & 279,43 & 91 & 3,07 & \\
\hline
\end{tabular}

Tabul'ka 1: Tabul'ka analýzy rozptylu pre didaktický test 15 - ročných žiakov

Tabul'ková hodnota $F_{(1,91)}(0,05)=3,95$ (Riečan et al, 1984,s. 302). Nakol'ko naša vypočítaná hodnota $\mathrm{F}=7,03>\mathrm{F}_{(1,91)}(0,05)=$ 3,95 , usudzujeme, že výsledky didaktického testu v jednotlivých skupinách sú rozdielne. Ked’že analýza rozptylu skončila signifikantným výsledkom, aplikovali sme ako doplnok štatistickej analýzy Duncanov test (tab. 2).

\begin{tabular}{|l|c|}
\hline $\mathrm{p}$ & 2 \\
\hline $\mathrm{q}_{0,05}(\mathrm{p}, 91)$ & 2,8 \\
\hline $\mathrm{s} \cdot \mathrm{q}_{0,05}(\mathrm{p}, 91)$ & 4,91 \\
\hline
\end{tabular}

Tabul'ka 2: Tabul'ka Duncanovho testu

Z tabul'ky analýzy rozptylu sme vypočítali s $=\sqrt{3,07}=1,75$. V špeciálnej tabul'ke (Šimková, 1985,s. 246) sme našli pre $\alpha=0,05$ a $\mathrm{n}-\mathrm{k}=77$ hodnoty $\mathrm{q}_{0,05}(\mathrm{p}, 77)$ a hladané medze. Platí:

$$
\left(\bar{x}_{2}-\bar{x}_{1}\right) \sqrt{\frac{2 n_{1} n_{2}}{n_{1}+n_{2}}}=6,57>4,91
$$

Hypotéza $\mathrm{H}(3)$ sa potvrdila na hladine významnosti $\alpha=0,05$. Pätnást'roční žiaci vyučovaní voblasti techniky na základných školách dosiahli $v$ didaktickom teste vyšší výkon v oblasti kognitívneho učenia ako žiaci vyučovaní na osemročných gymnáziách.

\section{Záver}

V našom výskume sme dospeli

k nasledovným výsledkom:

- Pätnást'roční žiaci základných škôl dosiahli v didaktickom teste priemernú relatívnu úspešnost' 41,5\%,
- Pätnást'roční žiaci osemročných gymnázií dosiahli v didaktickom teste priemernú relatívnu úspešnost' 35,3\%,

- Pätnást'roční žiaci základných škôl nedosiahli stanovený výkon 80 \%,

- Pätnástroční žiaci osemročných gymnázií nedosiahli stanovený výkon 80 \%,

- Pätnástroční žiaci vyučovaní v oblasti techniky na základných školách dosiahli v didaktickom teste vyšší výkon voblasti kognitívneho učenia ako žiaci vyučovaní na osemročných gymnáziách.

Uvedené výskumné údaje korešpondujú s výskumom a interpretáciou údajov iných autorov: Kuzmu (Kuzma, 1998, s. 31), Báneszom a Engelom (Engel, Bánesz, 1997, s. 54), Ďurišom (Ďuriš, 1999, s. 56), (Salata, 2007, s. 211), (Raczynska, 2007, s. 65). Na ich základe odporúčame prijat' pre vyučovanie technickej výchovy nasledujúce opatrenia:

- Vytvorit' podmienky pre realizáciu technickej výchovy v rozsahu 1 hodina týždenne na všetkých typoch škôl, na ktorých žiaci plnia povinnú školskú dochádzku,

- Prehodnotit' čiastočne obsah učebných osnov technickej výchovy z kvalitatívneho hl'adiska (aktualizácia technickej výchovy zodpovedajúca moderným trendom v oblasti techniky),

- Iniciovat' na katedrách technickej výchovy vytvorenie dostatočného počtu študijných materiálov pre učitel'ov a žiakov (pracovné zošity, metodické listy, multimédiá a i.), prispievajúcich $\mathrm{k}$ učebnej štrukturalizácii poznatkov, algoritmizácii postupov riešenia a zohl'adňujúcich rozličné stupne osvojenia ciel'a, na ktorý sa vzt'ahujú.

- Venovat' dôslednú pozornost' zabezpečeniu prípravy kvalifikovaných učitel'ov technickej výchovy v zmysle novej koncepcie všeobecného vzdelávania na ZŠ. V tejto súvislosti v pregraduálnej príprave učitel'ov systematicky vytvárat' kompetencie vzt'ahujúce sa na realizáciu technickej výchovy tak, aby bol splnený výkonový štandard predmetu.

\section{Literatúra}

RIEČAN et al: Pravdepodobnost' a štatistika. Bratislava: Alfa, 1984.

ŠIMKOVÁ, M.: Štatistika a matematické metódy. Bratislava: Príroda, 1985. 
KOMENDA, S. - KLEMENTA, J.: Analýza náhodného v pedagogickém experimentu. Praha: SPN, 1981.

KUZMA, J.: Vzdelávacie štandardy $\mathrm{v}$ technickej výchove. In: Zborník „Technické vzdelávanie ako súčast' všeobecného vzdelania", PF UMB, Banská Bystrica, 1998, s. 27 - 32, ISBN 80-85162-98-9.

ENGEL, T. - BÁNESZ, G.: K experimentu s jednoduchými strojmi a prevodmi v 5. ročníku ZŠ. In: Zborník Vplyv technickej výchovy na rozvoj osobnosti žiaka. Nitra: PF UKF, 1997, s. 54 - 57. ISBN 80-8050-169-6.

ĎURIŠ, M.: Postupy pri štandardizácii didaktických testov a ich praktická aplikácia. In: Acta universitas Matthiae Belii II, Banská Bystrica, 1999, s. 66 - 77. ISBN 80-8050-336$X$.

SALATA, E.: Motywy doksztalcania i doskonalenia oraz samoksztalcenia nauczycieli.
In: Wspólczesne problemy pedeutologii $i$ edukacji. Radom: Institut Technologii Eksploatacji, 2007, s. 208-212. ISBN 978-837204-649-9

RACZYNSKA, M.: Z badań nad wykorzystaniem wybranych form komunikacji na odległość. In: Technika-InformatykaEdukacja. Rzeszów: Uniwersytet Rzeszowski, 2007, s. 64-67. ISBN 978-83-88845-91-8

PaedDr. Danka Lukáčová, PhD.

Katedra techniky a informačných

technológií

PF UKF

Dražovská cesta 4

94974 Nitra

Slovenská republika

+421907670234

dlukacova@ukf.sk 